\title{
Genetic analyses of Bantam and selected low-weight White Plymouth Rock chickens and their crosses. I. Growth, immunoresponsiveness and carcass characteristics
}

\author{
EA Dunnington *, PB Siegel \\ Virginia Polytechnic Institute and State University \\ Poultry Science Department, Blacksburg, VA 24061-0332, USA
}

(Received 30 April 1990; accepted 18 January 1991)

\begin{abstract}
Summary - Two populations of small White Plymouth Rock chickens, one selected for low 8-wk body weight and the other a line of Bantam, were crossed to produce reciprocal $F_{1}$ 's. In the next generation, individuals of the parental and reciprocal $F_{1}$ populations were mated to produce all 16 possible populations including parentals, $\mathrm{F}_{1}$ 's, $\mathrm{F}_{2}$ 's and backcrosses. Because the Bantam had been developed to reach a small mature size and the line of low-weight selected chickens had been selected for low juvenile body weight, differences in growth patterns and carcass composition were apparent. Bantams weighed less at hatch and at maturity, but were heavier from 2-12 wk of age. Bantams also had proportionately more breast muscle and total body lipid than lowweight line pullets. Highly significant differences due to parental effects, heterosis and recombination loss occurred for body weights. Skeletal growth paralleled that of body weights. Immunoresponsiveness was not different in the 2 parental populations, and was not subject to heterosis or recombination loss.
\end{abstract}

selection / Bantam / chickens / growth / carcass

Résumé - Analyses génétiques de deux lignées de poules Plymouth Rock Blanche, l'une Bantam et l'autre sélectionnée pour un faible poids, et de leurs croisements. I. Croissance, aptitude à la réponse immunitaire et caractères de carcasse. Deux populations de petites poules de race Plymouth Rock Blanche, l'une sélectionnée pour un faible poids à 8 semaines, l'autre une lignée de Bantam, ont été croisées pour produire des $F_{1}$ réciproques. A la génération suivante, les individus des populations parentales et des $F_{1}$ ont été accouplés pour produire les 16 populations possibles incluant les parents, les $F_{1}$, les $\mathrm{F}_{2}$ et les croisements en retour. Puisque les Bantam avaient été produits en vue d'atteindre une faible taille adulte et que la lignée sélectionnée l'avait été pour un faible poids juvénile, des différences entre les 2 populations initiales dans la forme de la courbe de croissance et la composition de la carcasse étaient apparentes. Les Bantam étaient moins lourds à l'éclosion et au stade adulte, mais plus lourds entre 2 et 12 semaines d'âge. Les Bantam avaient aussi proportionnellement plus de muscle pectoral et de lipides corporels totaux que les poulets de la lignée à faible poids. Les effets parentaux d'hétérosis et de perte

\footnotetext{
* Correspondence and reprints
} 
de recombinaison étaient hautement significatifs pour les poids corporels. La croissance squelettique était parallèle à la croissance pondérale. L'aptitude à la réponse immunitaire ne différait pas d'une population parentale à l'autre et ne manifestait ni hétérosis ni perte de recombinaison.

sélection / Bantam / poule / croissance / carcasse

\section{INTRODUCTION}

Body weight of chickens is a complex trait that is readily modified by genetic and nongenetic factors. Genetically, there is considerable variation from polygenic influences and from major loci (see reviews by Siegel and Dunnington, 1987; Chambers, 1990). Numerous selection experiments have shown that body weight at specific ages may be increased or decreased by artificial selection. During domestication, many breeds and varieties of chickens were developed with a great range in body weight among them. At present, under ad libitum feeding, there is more than a 10-fold difference in adult body weight of Bantam and commercial meat-type chickens.

Because slow growth is generally not of economic importance in chickens, research emphasis has been on the inheritance of rapid growth. Also, because of interest in genetic improvement of a trait with moderate to high heritability, research has focused on responses to selection and, with a few notable exceptions (eg, Punnett and Bailey, 1914), crossing experiments involving slow-growing chickens are lacking. As is the case in selection for increased growth, intense selection for lower body weight reduces fitness. In large part, this artificial selection is successful because husbandry practices can be manipulated to compensate for reductions in natural fitness. For example, domesticated animals routinely are protected from starvation, climatic fluctuations, disease outbreaks and other adverse conditions by standard husbandry procedures. Excessive growth in parental stocks can be countered by feed restriction programs which allow circumvention of problems in reproduction. In some cases, however, limits to artificial selection are encountered which alterations in husbandry practices cannot ameliorate.

Long-term selection for low juvenile body weight in White Rock chickens has been accompanied by lack of appetite (Siegel et al, 1984) and reduced fitness (Dunnington et al, 1984). High mortality during the lst wk after hatch occurs because some of the chicks never learn to eat. Of those chicks that do survive, a portion are anorexic. That is, they eat enough food to maintain themselves, but not enough to mature sexually (Zelenka et al, 1988). In the last 6 generations of this 31-generation selection experiment, the limit for low body weight in these chickens had been approached 3 times, but has not been passed (Dunnington et al, 1987).

To study this population of low-weight chickens further, 2 generations of crossing with a White Plymouth Rock Bantam population were produced. The low-weight line of chickens was selected for reduced body weight at 8 wk of age, and the Bantams, through much longer and less intense selection, have evolved to resemble the White Plymouth Rock in body form, but as a miniature. Thus, the growth patterns of these 2 populations differ, although both are small and both suffer from reproductive dysfunctions. 
The objective of this work was to ascertain genetic influence on body and skeletal growth, immunoresponsiveness and carcass composition in parental, $F_{1}, F_{2}$ and backcross individuals from mating combinations of 2 selected populations: Bantam White Plymouth Rock and selected low-weight White Plymouth Rock populations. In a companion paper (Dunnington and Siegel, 1991), genetic comparisons of reproductive fitness among the populations will be reported.

\section{MATERIALS AND METHODS}

Fertile eggs from a flock of White Plymouth Rock Bantams were supplied by CJ Wabeck of the University of Maryland. Chicks from these eggs were reared to maturity and randomly mated to increase the population size. Then parental populations and reciprocal crosses were produced between the Bantam (B) and a line of White Plymouth Rocks (L) that had been selected for 31 generations for low 8-wk body weight (Dunnington and Siegel, 1985). A total of $103 \mathrm{~B}$ and $68 \mathrm{~L}$ fomales were inseminated with pooled semen from at least 10 males of the appropriate line to produce 4 populations: BB, BL, LB and LL (first letter designates sire line and second letter the dam line), which hatched on September 15, 1988 (generation 1). These chicks were reared to maturity $(175 \mathrm{BB}, 200 \mathrm{BL}, 205 \mathrm{LB}$ and 194 LL individuals) and used to produce the next generation. Twenty randomly chosen males per population were maintained to provide semen for production of the next generation. Samples of 75-80 pullets per population were divided into 4 groups and inseminated with pooled semen from appropriate lines to produce progeny from all mating combinations of lines $\mathrm{BB}, \mathrm{BL}, \mathrm{LB}$ and LL.

For generation 2 (hatched May 2, 1989), body weights of females were recorded at 2 -wk intervals through $12 \mathrm{wk}$, and every $4 \mathrm{wk}$ thereafter. For males body weights were recorded at 2 -wk intervals through $10 \mathrm{wk}$. Tibiotarsus (shank) lengths were recorded at $8 \mathrm{wk}$ of age.

Carcass data, measured at 9 wk of age in females, included the following weights: live body, defeathered carcass, breast muscles (pectoralis major and minor) and abdominal fat pad. Whole body lipid (minus feathers) was also obtained by chloroform-methanol extraction (Folch et al, 1957).

Antibody response was measured in cockerels at 5, 12 and $19 \mathrm{~d}$ after an intravenous injection of $0.1 \mathrm{ml}$ of a $0.25 \%$ suspension of SRBC given at 10 wk of age. Response was quantified by the microhemoagglutinin procedure of Wegmann and Smithies (1966).

Growth and carcass characteristics for the 16 populations were compared by analyses of variance. Contrasts were conducted to ascertain significant differences due to parental, reciprocal, heterosis and recombination effects. Specific contrasts are defined in the footnote of table I. Body weights were transformed to common logarithms and percentages to arc sine square roots prior to analyses. 
Table I. Means ${ }^{1} \pm$ SEM for body weights (BW), and shank lengths (SL) of males and females for all mating combinations of Bantam and low-weight chicken populations.

\begin{tabular}{|c|c|c|c|c|c|c|}
\hline \multirow[t]{2}{*}{ Population } & \multicolumn{3}{|c|}{ Males (wk) } & \multicolumn{3}{|c|}{ Females (wk) } \\
\hline & & $W(8)$ & $S L(8)$ & $B W(8)$ & $S L(8)$ & $B W(28)$ \\
\hline \multicolumn{7}{|l|}{ Parental } \\
\hline BBBB & 368 & $\pm 10 \mathrm{de}$ & $6.0 \pm 0.08 \mathrm{~d}$ & $317 \pm 8 \mathrm{~b}-\mathrm{e}$ & $5.7 \pm 0.17 \mathrm{c}$ & $808 \pm 27 \mathrm{~g}$ \\
\hline LLLL & 265 & $\pm 14 \mathrm{f}$ & $5.7 \pm 0.13 \mathrm{e}$ & $234 \pm 12 \mathrm{f}$ & $5.3 \pm 0.12 \mathrm{~d}$ & $1121 \pm 44 \mathrm{~cd}$ \\
\hline \multicolumn{7}{|l|}{$\mathrm{F}_{1}$} \\
\hline BBLL & 469 & $\pm 10 \mathrm{a}$ & $7.0 \pm 0.08 \mathrm{a}$ & $354 \pm 9 \mathrm{a}-\mathrm{c}$ & $6.1 \pm 0.09 \mathrm{ab}$ & $1071 \pm 21 \mathrm{~d}$ \\
\hline LLBB & 424 & $\pm 12 \mathrm{a}-\mathrm{c}$ & $7.0 \pm 0.08 \mathrm{ab}$ & $363 \pm 11 \mathrm{ab}$ & $6.3 \pm 0.09 \mathrm{a}$ & $1197 \pm 18 \mathrm{a}-\mathrm{c}$ \\
\hline \multicolumn{7}{|c|}{ - } \\
\hline BLBL & 393 & $\pm 13 \mathrm{~b}-\mathrm{d}$ & $6.4 \pm 0.08 \mathrm{c}$ & $326 \pm 12$ a-e & $5.8 \pm 0.11 \mathrm{bc}$ & $1050 \pm 37 \mathrm{de}$ \\
\hline BLLB & 431 & $\pm 18 \mathrm{a}-\mathrm{c}$ & $6.6 \pm 0.17 \mathrm{c}$ & $345 \pm 16 \mathrm{a}-\mathrm{d}$ & $6.1 \pm 0.14 \mathrm{ab}$ & $1131 \pm 36 \mathrm{~cd}$ \\
\hline LBBL & 398 & $\pm 14 \mathrm{~b}-\mathrm{d}$ & $6.5 \pm 0.09 \mathrm{c}$ & $323 \pm 11 \mathrm{~b}-\mathrm{e}$ & $5.9 \pm 0.08 \mathrm{bc}$ & $1120 \pm 33 \mathrm{~cd}$ \\
\hline LBLB & 400 & $\pm 15 \mathrm{~b}-\mathrm{d}$ & $6.6 \pm 0.09 \mathrm{bc}$ & $340 \pm 10$ a-d & $6.0 \pm 0.08 \mathrm{ab}$ & $1074 \pm 28 \mathrm{~d}$ \\
\hline \multicolumn{7}{|c|}{ Backcross to B } \\
\hline BBBL & 422 & $\pm 14 \mathrm{a}-\mathrm{c}$ & $6.4 \pm 0.08 \mathrm{c}$ & $369 \pm 12 \mathrm{a}$ & $5.9 \pm 0.10 \mathrm{a}-\mathrm{c}$ & $927 \pm 15 \mathrm{f}$ \\
\hline BBLB & 430 & $\pm 7 \mathrm{ab}$ & $6.6 \pm 0.07 \mathrm{bc}$ & $362 \pm 9 \mathrm{ab}$ & $6.0 \pm 0.08 \mathrm{ab}$ & $953 \pm 22$ ef \\
\hline BLBB & 390 & $\pm 9 \mathrm{~b}-\mathrm{d}$ & $6.4 \pm 0.08 \mathrm{c}$ & $344 \pm 9 a-d$ & $5.9 \pm 0.07 \mathrm{bc}$ & $925 \pm 34 \mathrm{f}$ \\
\hline LBBB & 423 & $\pm 10 \mathrm{a}-\mathrm{c}$ & $6.6 \pm 0.09 \mathrm{c}$ & $355 \pm 11 \mathrm{a}-\mathrm{c}$ & $6.0 \pm 0.09 \mathrm{ab}$ & $972 \pm 26$ ef \\
\hline \multicolumn{7}{|c|}{ Backcross to L } \\
\hline BLLL & 384 & $\pm 20 c-e$ & $6.4 \pm 0.16 c$ & $319 \pm 13 c-e$ & $5.9 \pm 0.13 \mathrm{a}-\mathrm{c}$ & $1212 \pm 35 \mathrm{a}-\mathrm{c}$ \\
\hline LBLL & 369 & $\pm 18 \mathrm{de}$ & $6.4 \pm 0.13 c$ & $294 \pm 10 \mathrm{e}$ & $5.7 \pm 0.08 \mathrm{bc}$ & $1169 \pm 48 \mathrm{~b}-\mathrm{d}$ \\
\hline LLBL & 354 & $\pm 24 \mathrm{e}$ & $6.4 \pm 0.18 c$ & $309 \pm 15 \mathrm{de}$ & $5.9 \pm 0.13 \mathrm{a}-\mathrm{c}$ & $1251 \pm 33 \mathrm{ab}$ \\
\hline LLLB & 385 & $\pm 15 \mathrm{~b}-\mathrm{e}$ & $6.7 \pm 0.18 \mathrm{bc}$ & $318 \pm 14$ c-e & $6.0 \pm 0.13 \mathrm{a}-\mathrm{c}$ & $1302 \pm 25 \mathrm{a}$ \\
\hline \multicolumn{7}{|l|}{ Contrasts $^{2}$} \\
\hline Parental & & $* *$ & $* *$ & $* *$ & $* *$ & $* *$ \\
\hline Reciproca & & - & - & - & - & $*$ \\
\hline Heterosis & & $* *$ & $* *$ & $* *$ & $* *$ & $* *$ \\
\hline Recombin & ation & $* *$ & $* *$ & $*$ & $*$ & - \\
\hline
\end{tabular}

$\mathrm{a}, \mathrm{b}, .$. Means within a column with the same letter are not significantly different $(P>0.05) .{ }^{1}$ Body weight in $\mathrm{g}$, shank length in $\mathrm{mm}$. Number of observations per mean ranged from 20-30. ${ }^{2}$ Contrasts: Parental = BBBB-LLLL. Reciprocal = BBLL-LLBB. Heterosis $=(\mathrm{BBLL}+\mathrm{LLBB})-(\mathrm{BBBB}+\mathrm{LLLL})$. Recombination $=(\mathrm{BLBL}+\mathrm{BLLB}+$ $\mathrm{LBBL}+\mathrm{LBLB})-2(\mathrm{BBLL}+\mathrm{LLBB}) . * *(P<0.01) ; *(P<0.05) ;-(P>0.05)$.

\section{RESULTS}

Mortality was $\approx 8 \%$ in pure line, low-weight chicks, a majority of which occurred during the lst wk after hatch. This is consistent with previous findings for this line, where a portion of individuals never learn to eat. There was very low mortality in all other populations $(<2 \%)$.

Growth patterns for the Bantam and low-weight selected populations reflect the types of selection to which they had been subjected (fig 1). At each age 
measured except 12 and $20 \mathrm{wk}$, body weights were significantly different for these 2 populations. At hatch the Bantam weighed less, but from 2-10 wk they were heavier than the low-weights. Hatch weight was a function of egg weight, which was lower for line B. Slowing of the growth rate for line $\mathrm{L}$ chicks in the juvenile stage resulted from the age at selection for this population. As the pullets matured, the Bantams weighed less, due to previous selection in the Bantams for reduced adult size. Comparison of linear regressions $\left(r^{2}=0.85\right)$ for growth of BBBB and LLLL populations indicated significantly different slopes.

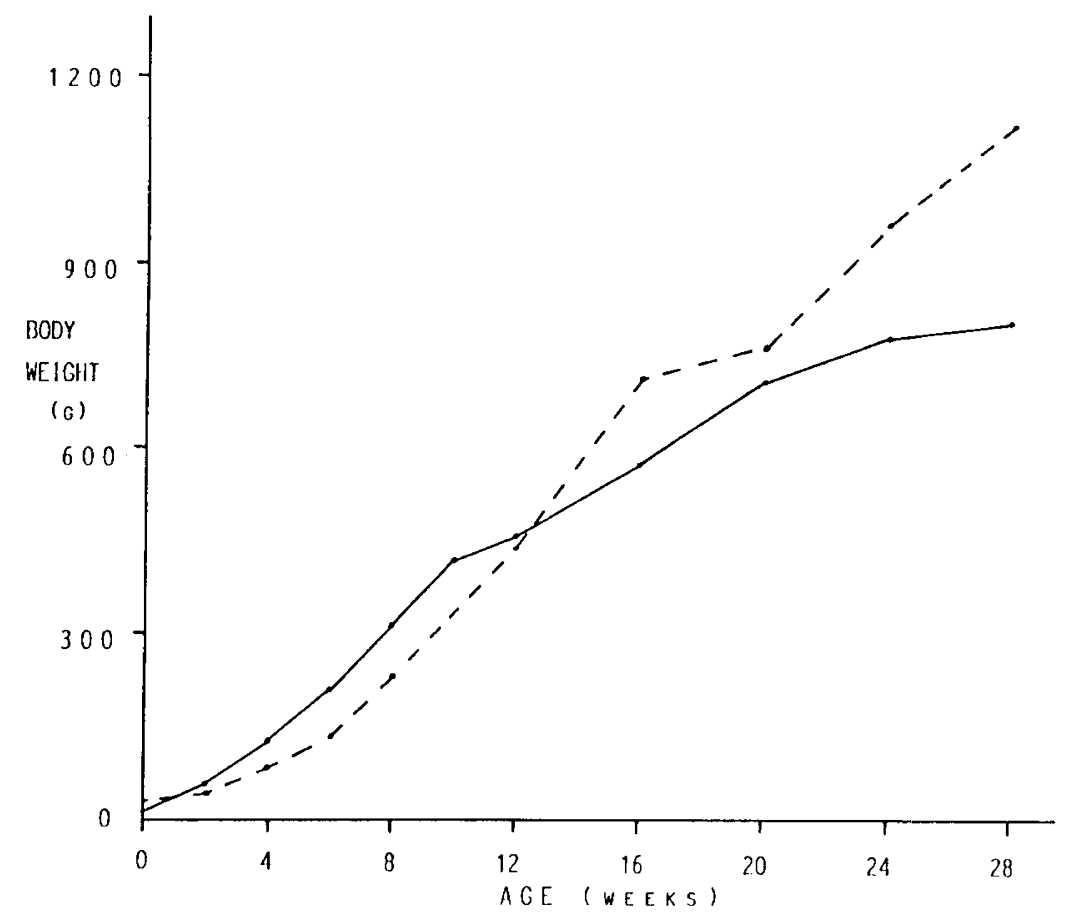

Fig 1. Growth curves for White Plymouth Rock Bantam (solid line) and White Plymouth Rock low-weight selected (broken line) populations - females from hatch to 28 wk of age.

Body weights of males and females from all populations at 8 and $28 \mathrm{wk}$ of age are shown in table I. All body weights except those at hatch were highly heterotic, ranging from $40-47 \%$ in males and $18-35 \%$ in females. There were differences between $F_{1}$ and $F_{2}$ populations for body weights at all ages in males and at most ages in females (data not shown), indicating recombination loss. Values for recombination loss ranged from -7 to $-14 \%$ in males and from 2 to $-8 \%$ in females.

Effects which were significant in assessing shank length were parental, heterosis and recombination in both sexes (table I). Shank lengths are shown for males and females of all populations at 8 wk of age. Shanks of Bantam were significantly longer than those of low-weight chicks at $8 \mathrm{wk}$ of age, but the relationship reversed for mature birds (data not shown) as was the case for body weight. Percentages of 
heterosis for shank length at $8 \mathrm{wk}$ of age were $20 \%$ for males and $13 \%$ for females. Recombination losses of $-9 \%$ (males) and $-3 \%$ (females) were found.

Because there were highly significant differences among populations in body weights, carcass data at 9 wk of age were expressed as percentages of body weight (table II). Mean values for the 16 mating combinations are given for $\%$ breast, $\%$ heart, $\%$ lung, $\%$ abdominal fat and $\%$ body lipid. Parental lines were different for $\%$ breast, \% lung and \% body lipid, with Bantam having higher percentages of breast and body lipid. Reciprocal effects were significant only for \% breast. Although reciprocal effects for \% body lipid appear large, there was high variability associated with this trait. Significant heterotic effects occurred for $\%$ breast (12\%), \% heart $(-13 \%), \%$ lung $(15 \%)$ and \% body lipid (26\%). Recombination loss was significant for $\%$ breast $(-12 \%)$ and $\%$ lung $(-9 \%)$.

Table II. Means ${ }^{1} \pm$ SEM for carcass traits (expressed as a percent of body weight) of female chickens at 9 wk of age in all mating combinations of Bantam and low-weight populations.

\begin{tabular}{|c|c|c|c|c|c|c|}
\hline Populations & \multicolumn{2}{|c|}{ Breast } & Heart & Lung & Abdominal fat & Lipid \\
\hline \multicolumn{7}{|l|}{ Parental } \\
\hline BBBB & \multicolumn{2}{|c|}{$10.17 \pm 0.32 \mathrm{ab}$} & $0.59 \pm 0.02 \mathrm{ab}$ & $0.54 \pm 0.02 \mathrm{~d}$ & $0.41 \pm 0.07 \mathrm{a}-\mathrm{c}$ & $9.04 \pm 0.55 \mathrm{a}-\mathrm{e}$ \\
\hline LLLL & & $\pm 0.24 \mathrm{f}$ & $0.65 \pm 0.04 \mathrm{a}$ & $0.63 \pm 0.02 \mathrm{a}-\mathrm{d}$ & $0.20 \pm 0.10 \mathrm{bc}$ & $6.03 \pm 0.54 \mathrm{f}$ \\
\hline \multicolumn{7}{|l|}{$\mathrm{F}_{1}$} \\
\hline BBLL & \multirow{2}{*}{\multicolumn{2}{|c|}{$\begin{aligned} 10.91 & \pm 0.23 \mathrm{a} \\
9.49 & \pm 0.42 \mathrm{~b}-\mathrm{d}\end{aligned}$}} & $0.57 \pm 0.03 \mathrm{ab}$ & $0.68 \pm 0.04 \mathrm{a}$ & $0.64 \pm 0.17 \mathrm{a}$ & $10.50 \pm 1.69 \mathrm{ab}$ \\
\hline LLBB & & & $0.51 \pm 0.02 \mathrm{~b}$ & $0.66 \pm 0.03 \mathrm{a}-\mathrm{c}$ & $0.44 \pm 0.10 \mathrm{ab}$ & $8.50 \pm 0.81 \mathrm{a}-\mathrm{f}$ \\
\hline \multicolumn{7}{|l|}{$\mathrm{F}_{2}$} \\
\hline BLBL & \multicolumn{2}{|c|}{$9.38 \pm 0.30 \mathrm{~b}-\mathrm{e}$} & $0.57 \pm 0.04 \mathrm{ab}$ & $0.59 \pm 0.02 \mathrm{a}-\mathrm{d}$ & $0.47 \pm 0.12 \mathrm{ab}$ & $9.85 \pm 0.45 \mathrm{a}-\mathrm{c}$ \\
\hline BLLB & \multirow{2}{*}{\multicolumn{2}{|c|}{$\begin{array}{l}9.26 \pm 0.42 \mathrm{~b}-\mathrm{e} \\
8.70 \pm 0.35 \mathrm{~d}-\mathrm{f}\end{array}$}} & $0.61 \pm 0.02 \mathrm{ab}$ & $0.61 \pm 0.01 \mathrm{a}-\mathrm{d}$ & $0.68 \pm 0.16 \mathrm{a}$ & $10.85 \pm 0.92 \mathrm{a}$ \\
\hline LBBL & & & $0.60 \pm 0.02 \mathrm{ab}$ & $0.61 \pm 0.04 \mathrm{a}-\mathrm{d}$ & $0.52 \pm 0.10 \mathrm{ab}$ & $8.34 \pm 0.39$ a-e \\
\hline LBLB & \multicolumn{2}{|c|}{$8.28 \pm 0.43$ ef } & $0.58 \pm 0.04 \mathrm{ab}$ & $0.63 \pm 0.03 \mathrm{a}-\mathrm{d}$ & $0.31 \pm 0.12 \mathrm{a}-\mathrm{c}$ & $9.10 \pm 0.99$ a-e \\
\hline \multicolumn{7}{|c|}{ Backcross to B } \\
\hline BBBL & \multirow{2}{*}{\multicolumn{2}{|c|}{$10.89 \pm 0.21 \mathrm{a}$}} & $0.61 \pm 0.02 \mathrm{ab}$ & $0.59 \pm 0.03 \mathrm{a}-\mathrm{d}$ & $0.51 \pm 0.10 \mathrm{ab}$ & $9.16 \pm 0.56 \mathrm{a}-\mathrm{e}$ \\
\hline BBLB & & & $0.54 \pm 0.02 \mathrm{ab}$ & $0.57 \pm 0.06 \mathrm{~b}-\mathrm{d}$ & $0.67 \pm 0.27 \mathrm{a}$ & $10.57 \pm 2.05 \mathrm{ab}$ \\
\hline BLBB & \multicolumn{2}{|c|}{$9.15 \pm 0.31 \mathrm{~b}-\mathrm{f}$} & $0.63 \pm 0.09 \mathrm{ab}$ & $0.56 \pm 0.02 \mathrm{~cd}$ & $0.45 \pm 0.18 \mathrm{a}-\mathrm{c}$ & $9.09 \pm 1.14$ a-e \\
\hline LBBB & \multicolumn{2}{|c|}{$9.87 \pm 0.25 \mathrm{a}-\mathrm{c}$} & $0.55 \pm 0.05 \mathrm{ab}$ & $0.62 \pm 0.05 \mathrm{a}-\mathrm{d}$ & $0.48 \pm 0.11 \mathrm{ab}$ & $9.70 \pm 1.08 \mathrm{a}-\mathrm{d}$ \\
\hline \multicolumn{7}{|c|}{ Backcross to L } \\
\hline BLLL & \multicolumn{2}{|c|}{$9.50 \pm 0.51 \mathrm{~b}-\mathrm{d}$} & $0.62 \pm 0.03 \mathrm{ab}$ & $0.68 \pm 0.02 \mathrm{a}$ & $0.24 \pm 0.11 \mathrm{a}-\mathrm{c}$ & $7.14 \pm 0.57 \mathrm{c}-\mathrm{f}$ \\
\hline LBLL & \multicolumn{2}{|c|}{$9.08 \pm 0.45 b-f$} & $0.53 \pm 0.01 \mathrm{ab}$ & $0.67 \pm 0.02 \mathrm{ab}$ & $0.37 \pm 0.08 \mathrm{a}-\mathrm{c}$ & $7.39 \pm 0.57 \mathrm{~b}-\mathrm{f}$ \\
\hline LLBL & \multicolumn{2}{|c|}{$8.91 \pm 0.23 \mathrm{c}-\mathrm{f}$} & $0.55 \pm 0.03 \mathrm{ab}$ & $0.65 \pm 0.02 \mathrm{a}-\mathrm{c}$ & $0.17 \pm 0.05 \mathrm{bc}$ & $6.79 \pm 0.22 \mathrm{~d}-\mathrm{f}$ \\
\hline LLLB & \multicolumn{2}{|c|}{$8.48 \pm 0.38 \mathrm{~d}-\mathrm{f}$} & $0.65 \pm 0.07 \mathrm{ab}$ & $0.63 \pm 0.02 \mathrm{a}-\mathrm{d}$ & $0.13 \pm 0.06 \mathrm{c}$ & $6.74 \pm 0.62$ ef \\
\hline \multicolumn{7}{|l|}{ Contrasts $^{2}$} \\
\hline Parental & & $* *$ & - & $*$ & - & $*$ \\
\hline Reciprocal & & $* *$ & - & - & - & - \\
\hline Heterosis & & $* *$ & $*$ & $* *$ & - & $*$ \\
\hline Recombina & tion & $* *$ & - & $*$ & - & - \\
\hline
\end{tabular}

$\mathrm{a}, \mathrm{b}, .$. Means within a column with the same letter are not significantly different $(P>0.05) .{ }^{1}$ Number of observations per mean $=5 .^{2}$ Description of contrasts same as for table I. 
Antibody responses to SRBC were not different between parental populations (mean $\pm \mathrm{SE}$ for $\mathrm{BBBB}=7.8 \pm 0.4$, for $\mathrm{LLLL}=7.1 \pm 0.4$ ) and showed no reciprocal, heterotic or recombination effects.

\section{DISCUSSION}

Selection for small body size has not been reported extensively in the scientific literature, perhaps because reduced body size is not economically advantageous in agricultural animals. The testing of genetic theory for selection for lower body weight is, however, as interesting as that for upward selection, particularly as it influences correlated traits. Also there is interest in developing small individuals in some species, generally for novelties such as toy dogs, miniature horses and bantam chickens. As is the case with intense selection for most traits, the criterion of selection is not the only characteristic altered during genetic manipulation. The ability of an organism to maintain a balance of soft tissue mass (muscles, lipid, etc), integral internal organs (heart, lungs), skeletal support, hormonal environment and immunoresponsiveness when the population has undergone intense artificial selection for altered body weight is an excellent example of buffering capacity that has developed during evolution.

The 2 parental populations used in this study had been subjected previously to selection which reduced their body size. The Bantams evolved into miniaturized mature individuals, whereas the low-weight chickens were selected for low juvenile body weight with no selection pressure devoted to body form or shape. These differences in criteria of selection have caused the populations to display very different growth patterns, evident in both body weights and in skeletal development. Proportions of $\%$ body lipid and $\%$ breast were also consistent with the difference in selection criteria.

Exceptionally high levels of heterosis for body weight may have resulted from previous artificial selection for reduced body weight and from accompanying levels of inbreeding in the 2 parental populations which have been closed for an extended period. Presumably, selection in the 2 parental populations had increased frequencies of different genes influencing small size because the selection criteria were quite different. Crossing to produce the $F_{1}$ populations reduced the effects of these genes, resulting in high levels of heterosis. Subsequent segregation in the $F_{2}$ populations resulted in considerable recombination loss.

By measuring size of organs, an idea of the proportional growth of different body parts can be ascertained. In this experiment, there were no differences between the 2 parental populations in weights of feather, abdominal fat or heart (all expressed as $\%$ of body weight). Neither heterosis nor reciprocal effects were evident for $\%$ feather or $\%$ abdominal fat, although there was significant negative heterosis for $\%$ heart. Artificial selection for reduced body weight in both parental populations had apparently been accompanied by the influence of natural selection to maintain a balance of organ size proportional to body weight for these components.

Conversely, $\%$ breast and \% body lipid were higher in Bantams than low-weights, presumably due to selection in the Bantams for a mature form that resembled that of the White Plymouth Rock breed. It is curious that \% lung was higher in $\mathrm{L}$ pullets than $B$ pullets and also that, while heterosis for $\%$ heart was significant and 
negative, heterosis for \% lung was significant and positive. This difference in mode of inheritance for relative heart and lung in weight-selected populations is of interest because one is of mesodermal (heart) and the other of entodermal (lung) origin. Moreover, it suggests a basis for the severe problems experienced in fast-growing broilers that become susceptible to sudden death syndrome and ascites (eg, Julian, 1989).

Chickens selected for reduced body weight were able to maintain a physiological equilibrium allowing them to function effectively, even though body size had changed dramatically. Subsequent generations of crossing have given us insight into the effects of artificial selection, correlated responses, modes of inheritance and associated force of natural selection.

\section{REFERENCES}

Chambers JR (1990) Genetics of growth and meat production in chickens. In: Poultry Breeding and Genetics (Crawford RD, ed) Elsevier Science Publishers, 599-644

Dunnington EA, Siegel PB, Cherry JA (1984) Delayed sexual maturity as a correlated response to selection for reduced 56-day body weight in White Plymouth Rock pullets. Arch Gefluegelkd 48, 111-113

Dunnington EA, Siegel PB (1985) Long-term selection for 8-week body weight in chickens - Direct and correlated responses. Theor Appl Genet 71, 305-313

Dunnington EA, Zelenka DJ, Siegel PB (1987) Sexual maturity in selected lines of chickens. Proc Br Poult Breeders' Round Table, Edinburgh, Scotland, Sept 16-18 Dunnington EA, Siegel PB (1991) Genetic analyses of Bantam and selected lowweight White Plymouth Rock chickens and their crosses. II. Onset of sexual maturity and egg production. Genet Sel Evol 23, 149-157

Folch J, Lees M, Sloane-Stanley GH (1957) A simple method for the isolation and purification of total lipids from animal tissues. $J$ Biol Chem 226, 497-509

Julian RJ (1989) Pulmonary hypertension causing right heart failure and ascites (waterbelly) in meat-type chickens. 24th Natl Meeting Poult Health and Condemnations Proc Delmarva Poultry, 108-113

Punnett RC, Bailey PB (1914) On inheritance of weight in poultry. $J$ Genet, iv, 23-39

Siegel PB, Dunnington EA (1985) Reproductive complications associated with selection for broiler growth. In: Poultry Genetics and Breeding (Hill WG, Manson $\mathrm{JH}$, Hewitt D, eds) Longman Group, Harlow, 59-72

Siegel PB, Dunnington EA (1987) Selection for growth in chickens. In: CRC Critical Reviews in Poultry Biology. CRC Press Inc, 1-24

Siegel PB, Cherry JA, Dunnington EA (1984) Feeding behaviour and feed consumption in chickens selected for body weight. Ann Agric Fenn 23, 247-252

Wegmann TG, Smithies O (1966) A simple hemagglutination system requiring small amounts of red cells and antibodies. Transfusion 6, 67-73

Zelenka DJ, Dunnington EA, Cherry JA, Siegel PB (1988) Anorexia and sexual maturity in female White Rock chickens. I. Increasing feed intake. Behav Genet 18, $383-387$ 